Tarbawy : Jurnal Pendidikan Islam

ISSN : 2407-4462 (Cetak), 2614-5812 (Elektronik)

Vol. 8, No. 1, 2021, pp. 13-18

DOI: https://doi.org/10.32923/tarbawy.v8i1.1540

\title{
Analisis Keefektifan Pembelajaran Jarak Jauh Pendidikan Agama Islam di Masa Pandemi COVID-19 di SD Negeri 17 Pangkalpinang
}

\author{
Fedrata Erdinansyah $^{1}$, Siti Hawa ${ }^{2}$, Susi Suryani ${ }^{3}$, Yusmita $^{4}$, Wahyudin Noor ${ }^{5}$
}

${ }^{1}$ IAIN Syaikh Abdurrahman Siddik Bangka Belitung

${ }^{2}$ IAIN Syaikh Abdurrahman Siddik Bangka Belitung

${ }^{3}$ IAIN Syaikh Abdurrahman Siddik Bangka Belitung

${ }^{4}$ IAIN Syaikh Abdurrahman Siddik Bangka Belitung

${ }^{5}$ IAIN Syaikh Abdurrahman Siddik Bangka Belitung

\begin{tabular}{l}
\hline Info Artikel : \\
\hline Diterima 14 januari 2021 \\
Direvisi 12 maret 2021 \\
Dipublikasikan 30 april 2021 \\
\\
Kata Kunci: \\
Pembelajaran Jarak Jauh (PJJ) \\
Efektifitas Belajar \\
Pandemi Covid-19
\end{tabular}

Keywords:

Distance Learning

Learning Effectiveness

Covid-19 Pandemic

\begin{abstract}
ABSTRAK
Penelitian ini bertujuan untuk menganalisis keefektifitasan Pembelajaran Jarak Jauh (PJJ) pada mata pelajaran Pendidikan Agama Islam (PAI) di masa pandemi Covid-19 di SD Negeri 17 Pangkalpinang. Penelitian ini merupakan penelitian deskripif kualitatif. Responden yang berkaitan dalam penelitian ini berjumlah 5 orang terdiri dari 2 guru dan 3 peserta didik. Teknik pengambilan sampel yang digunakan adalah teknik purposive sampling. Data dikumpulkan menggunakan wawancara (interview) jenis semistruktural yang terdiri dari 6 pertanyaan. Data kualitatif tersebut dianalisis menggunakan analisis tematik. Berdasarkan hasil penelitian yang dilakukan adalah Pembelajaran Jarak Jauh (PJJ) kurang efektif karena kurangnya fasilitas, tingkat semangat peserta didik yang rendah, serta nilai dan hasil pembelajaran tidak dapat diukur dengan pasti.
\end{abstract}

\begin{abstract}
This study aims to analyze the effectiveness of Distance Learning in Islamic Religious Education subjects during the Covid-19 pandemic at SD Negeri 17 Pangkalpinang. This research is a descriptive study with a qualitative approach. In this study, the respondents involved were 5 people consisting of 2 teachers and 3 students. The sampling technique used was purposive sampling technique. The data were collected using semistructured interview which consisted of 6 questions. The qualitative data were analyzed using thematic analysis. Based on the results of research conducted, Distance Learning is less effective due to lack of facilities, low level of enthusiasm for students, also scores and learning outcomes cannot be measured with certainty.
\end{abstract}

\section{Koresponden:}

Fedrata Erdinansyah

Email: fedrataerdinansyah@gmail.com

This is an open access article distributed under the Creative Commons Attribution License, which permits unrestricted use, distribution, and reproduction in any medium, provided the original work is properly cited. (C2019 by author.

\section{Pendahuluan}

Tahun 2020 merupakan tahun yang sulit, kita dikejutkan dengan adanya wabah virus Covid-19 yang mewabah dan menginfeksi hampir ke seluruh dunia, tidak terkecuali negara kita Indonesia. Covid-19 (Coronavirus Disease 2019) merupakan penyakit yang disebabkan virus corona jenis baru yang diduga berasal dari Wuhan, Hubei, China di tahun 2019,(Hui et al., 2020) .Jumlah orang-orang yang terpapar terus naik dengan cukup signifikan pada waktu yang relatif cepat. Berdasarkan data yang diperoleh, per 10 November 2020, jumlah terpapar Covid-19 di Indonesia mencatat angka 444.348 jiwa. Sementara itu, di Bangka Belitung sendiri yang terpapar Covid-19 telah mencapai 696 jiwa , (Telaumbanua, 2020).

Kondisi pandemi Covid-19 ini berdampak pada hampir semua bidang di kehidupan manusia, tidak terkecuali bidang Pendidikan. Banyak negara di dunia memilih untuk menghentikan aktivitas belajar tatap 
muka di berbagai institusi pendidikan, termasuk Indonesia. Oleh karena itu, pemerintah Indonesia mau tidak mau harus membuat keputusan berat untuk menutup institusi pendidikan dalam upaya menghnetikan penyebaran virus dan menyelamatkan nyawa tenaga pendidik maupun peserta didik. Hal ini dilakukan atas himbauan WHO yang meminta untuk menghentikan acara-acara yang dapat menyebabkan orang-orang berkerumun dan menerapkan social distancing dan physical distancing dalam rangka menghentikan rantai penyebaran virus, (Kahfi, 2020).

Masuknya Covid-19 ke Indonesia menyebabkan proses pembelajar dialihkan menjadi Pembelajaran Jarak Jauh (PJJ) atau Belajar dari Rumah (BDR) hampir di sebagian besar wilayah Indonesia. Karenanya, yang semulanya menggunakan metode tatap muka seperti kontak fisik dan ceramah berubah menjadi Pembelajaran Jarak Jauh. Pembelajaran Jarak Jauh dilaksanakan oleh tiap institusi pendidikan dalam rangka menghentikan penyebaran virus Covid-19 dan demi keselamatan tenaga pendidik dan peserta didik , (Maulah \& Ummah, 2020). Menurut Dohmen (1967), Pembelajaran Jarak Jauh (PJJ) didefinisikan sebagai pembelajaran mandiri yang sistemastis, yang mana konseling, pemberian materi, dan pengawasan serta pemantauan keberhasilan peserta didik yang dilakukan oleh guru sebagai penanggung jawab. Bantuan media diperlukan untuk pelaksanaan pembelajaran jarak jauh. Kebalikan dari Pembelajaran jarak jauh adalah tatap muka atau langsung, yaitu pembelajaran secara kontak langsung anatara guru dan peserta didik.

Menteri Pendidikan dan Kebudayaan Republik Indonesia mengeluarkan Surat Edaran No. 4 Tahun 2020 Tentang Pelaksanaan Kebijakan Pendidikan Dalam Masa Darurat Penyebaran Covid-19 poin ke dua yaitu proses belajar dari rumah dilaksanakan dengan ketentuan sebagai berikut:

a. Dilaksanakan untuk memberikan pengalaman belajar yang bermakna tanpa terbebani tuntutan menuntaskan seluruh capaian kurikulum untuk kenaikan kelas ataupun kelulusan

b. Difokuskan pada pendidikan kemampuan hidup mengenai pandemi Covid-19

c. Aktivitas dan tugas pembelajaran dapat bervariasi, sesuai dengan kondisi dan minat antarsiswa, temasuk mempertimbangkan ada atau tidaknya fasilitas/akses belajar dari rumah.

d. Bukti atau produk aktivitas belajar diberi feedback yang bersifat kualitatif dan berguna dari guru, tanpa dituntut untuk memberi nilai kuantitatif.

Dengan adanya Surat Edaran tersebut, proses pembelajaran jarak jauh berpengaruh sangat besar terhadap dunia pendidikan dan dirasakan oleh berbagai pihak terutama tenaga pendidik dan peserta didik. Pelaksanaan Pembelajaran jarak Jauh (PJJ) atau Belajar dari Rumah (BDR) ini juga dilakukan oleh SD Negeri 17 Pangkalpinang. Berdasarkan kondisi yang terjadi di masa pademi Covid-19 dan juga beberapa kajian teori, maka tujuan dari penelitian ini yaitu untuk menganalisis keefektifitasan Pembelajaran Jarak Jauh (PJJ) pada mata pelajaran Pendidikan Agama Islam (PAI) selama pandemi Covid-19 di SD Negeri 17 Pangkalpinang.

\section{Metode}

Penelitian ini menggunakan metode deskriptif kualitatif untuk memperoleh informasi mengenai pembelajaran jarak jauh di masa pandemi Covid-19. Metode penelitian kualitatif adalah metode penelitian naturalis, hal ini dikarenakan penelitiannya dilakukan saat kondisi natural atau alamiah, lalu data dianalisis secara kualitatif. (Sugiyono, 2015:15) Metode ini terbilang relevan untuk menggambarkan kondisi dimasa sekarang dan menjadi latar belakang penelitian yaitu mengenai Pembelajaran Jarak jauh di masa pandemic Covid-19

Responden yang berkaitan dalam penelitian ini berjumlah 5 orang dari SD Negeri 17 Pangkalpinang, yakni 2 guru dan 3 peserta didik. Agar kerahasiaan identitas responden terjaga, peneliti membuat inisial responden menjadi R1, R2, R3, R4 dan R5. Purposive sampling dipilih peneliti sebagai teknik pengambilan sampel. Purposive sampling adalah teknik sampling dengan tidak berdasarkan random, strata atau daerah, tapi berdasarkan kesengajaan dengan adanya pertimbangan yang berfokus pada tujuan tertentu. Jika tidak ada unsur kesengajaan, kondisi tersebut akan membuat peneliti mengalami kesulitan dalam mendapatkan dan memilih sample, (Suharsimi, 2006). 
Tabel 1. Responden

\begin{tabular}{|c|c|c|c|c|}
\hline Inisial & Jenis Kelamin & Jabatan & Usia & $\begin{array}{c}\text { Pendidikan } \\
\text { Terakhir }\end{array}$ \\
\hline R1 & Perempuan & Guru & 43 & S1 \\
\hline R2 & Perempuan & Guru & 47 & D2 \\
\hline R3 & Laki-laki & Peserta Didik & 10 tahun & SD \\
\hline R4 & Perempuan & Peserta Didik & 11 tahun & SD \\
\hline R5 & Laki-laki & Peserta Didik & 9 Tahun & SD \\
\hline
\end{tabular}

Selain itu, teknik pengumpulan data yang baik akan menghasilkan data yang baik pula. Teknik pengumpulan data yang digunakan dalam penelitian ini adalah wawancara (interview). Penggunaan Teknik ini karena peneliti menganggap bahwa permasalahan yang diteliti cukup dinamis dan kompleks, jadi data yang diperoleh dari narasumber didapatkan dengan metode yang alamiah yakni wawancara (interview) langsung dengan narasumber sehingga mendapatkan jawaban yang alamiah. Jenis wawancara semistruktural (semistructured interview) digunakan pada penelitian ini. Jenis wawancara ini sudah termasuk dalam kategori in-depth interview, yang mana pelaksanaannya lebih bebas dibandingkan wawancara terstruktur. Tujuannya yakni untuk menemukan permasalahan secara lebih terbuka, dengan cara narasumber dimintai ide-ide dan pendapatnya. Saat melakukan wawancara, peneliti harus mencatat dan mendengarkan dengan teliti tentang apa yang dikemukakan narasumber. (Sugiyono, 2015:320)

Analisis data yang digunakan yaitu analisis data tematik, digunakan karena pendekatan tematik dapat menghasilkan analisis yang mendalam untuk menjawab pertanyaaan. Clarke dan Braun menyatakan bahwa tujuan analisis tematik bertujuan untuk menentukan tema, yaitu pola yang penting atau menarik dari data dan memakai tema tersebut untuk menjawab atau membahas suatu masalah, (Utarini, 2020).

Adapaun indikator-indikator pembelajaran yang efektif seperti: 1) pengelolaan pelaksanaan pembelajaran, 2) proses komunikatif, 3) tanggapan peserta didik, 4) aktifitas belajar, 5) hasil belajar. Dengan begitu, pembelajaran dikatakan efektif apabila semua indikator tersebut dalam kategori minimal baik, (Bistari, 2017).

Agar temuan dapat dianalisis, peneliti mengajukan pertanyaan-pertanyaan yang telah disusun kepada responden sebagai bahan untuk menggali dan mendapatkan informasi. Pertanyaan-pertanyaan yang diajukan sebagai berikut:

1. Ada berapakah jumlah peserta didik di SD Negeri 17 Pangkalpinang ?

2. Bagaimana tanggapan mengenai proses belajar yang dijalani sekarang ?

3. Bagaimana dampak covid-19 terhadap proses belajar yang dijalani peserta didik ?

4. Sejak kapan metode Pembelajaran Jarak Jauh (PJJ) ini diterapkan dan bagaimana proses pembelajarannya?

5. Efektifkah proses pembelajaran PAI yang dijalani dalam mencapai harapan dari kegiatan belajar peserta didik?

6. Bagaimana nilai dan hasil belajar peserta didik pada mata pelajaran PAI setelah melaksanakan Pembelajaran Jarak Jauh (PJJ)?

\section{Hasil}

Hasil penelitian berupa pernyataan yang disampaikan responden saat wawancara semi struktur yang dilakukan secara langsung. Pernyataan ini berasal dari bukti lapangan mengenai apa yang dirasakan oleh 
responden terkait. Adapun hasil penelitian yang diperoleh dari wawancara dengan responden terkait sebagai berikut.

Peserta didik di SD Negeri 17 Pangkalpinang kurang lebih berjumlah 260 siswa yang terdiri dari 8 rombel. SD Negeri 17 Pangkalpinang menerapkan metode Pembelajaran Jarak Jauh (PJJ) sejak diterbitkannya surat Edaran dari Kementerian Pendidikan dan Kebudayaan yaitu tanggal 26 Maret 2020. Proses metode pembelajaran ini pun berjalan lancar, yang mana pembelajaran dimulai dengan guru membuat materi dan tugas pembelajaran yang kemudian diserahkan kepada orangtua ataupun peserta didik. Bagi orangtua ataupun peserta didik yang kekurangan fasilitas seperti handphone atau kuota internet, mereka dianjurkan untuk mengambil materi dan tugas tersebut ke sekolah, lalu dikerjakan dan dikumpulkan satu minggu kemudian. Sedangkan bagi mereka yang memiliki fasilitas memadai, guru akan membagikan materi dan tugas secara daring dan dapat dikumpulkan secara daring pula (R1 dan R2, 2020).

Proses pembelajaran ini ditanggapi kurang baik oleh para guru. Hal ini disebabkan guru tidak bisa memantau dan berinteraksi langsung dengan para peserta didik dikarenakan pembelajaran jarak jauh dan adanya himbauan untuk tidak berkerumunan serta selalu menjaga kesehatan dan keselamatan diri. Pembelajaran juga tidak dapat tersampaikan sepenuhnya kepada peserta didik, karena kebanyakan yang menggantikan mereka belajar di rumah adalah orangtua maupun saudaranya (R1 dan R2, 2020). Peserta didik pun menanggapi pembelajaran ini dengan kurang baik, mereka merasa bosan dirumah, tidak adanya teman, dan tugas yang lebih banyak daripada pembelajaran tatap muka. Hal ini membuat semangat dan motivasi siswa dalam belajar berkurang (R3, R4 dan R5, 2020).

R1 dan R2 (2020) menyatakan pandemi Covid-19 juga berdampak terhadap proses belajar yang dijalani peserta didik. Belajar dengan metode ini adalah budaya baru di SD Negeri 17 Pangkalpinang. Peserta didik pun mau tidak mau harus menyesuaikan diri dengan metode ini. Namun, seperti yang diketahui, tidak semua orangtua dan peserta didik memiliki fasilitas belajar seperti handphone dan kuota internet. Jadi guru pun mengajar dengan mempertimbangkan kemampuan fasilitas tiap orangtua dan peserta didik, tanpa membuat mereka merasa terbebani. Jadi pembelajaran didapatkan secara merata dan fair. Peserta didik menanggapi proses yang dijalani saat ini dengan kurang semangat dan belajar serasa membosankan karena mereka tidak dapat bertemu dengan teman-teman dan banyaknya tugas yang diberikan hampir setiap hari (R3, R4 dan R5, 2020).

Adapun jika dilihat dari keefektifannya. Menurut R1 dan R2 (2020), apabila dibandingkan dengan pembelajaran tatap muka, pembelajaran jarak jauh ini pastinya kurang efektif. Tiap individu itu berbeda, secara tatap muka saja tidak semua peserta didik paham akan materi yang disampaikan oleh guru, apalagi belajar dari rumah seperti ini. Tapi bagaimanapun kebijakan Kementrian harus dipatuhi, sekarang dunia pendidikan dalam kondisi yang darurat yang mana keselamatan jiwa adalah yang utama. Semuanya terjadi secara tiba-tiba dan guru harus mengubah metode belajar tiba-tiba juga. Selain itu, pembelajaran ini dapat dikatakan efektif ataupun tidak apabila dilihat dari kesanggupan orangtua dan peserta didik dalam memiliki fasilitas belajar. Peserta didik pun menanggapi pembelajaran jarak jauh ini dengan kurang efektif, karena shock akan metode baru ini dan kurangnya motivasi mereka dalam belajar (R3, R4 dan R5, 2020).

Nilai dan hasil belajar peserta didik pun tidak dapat diukur secara pasti. Guru tidak dapat memastikan ada atau tidaknya peningkatan penguasaan materi. Hal ini dikarenakan materi dan tugas yang diberikan oleh guru, $90 \%$ bukan dikerjakan oleh peserta didik, melainkan orangtua atau saudara mereka. Oleh karena itu, kemampuan mereka tidak dapat dipantau. Beda halnya dengan pembelajaran tatap muka, yang mana guru dapat mengetahui kemampuan mereka sebenarnya dengan memantau perkembangan penguasaan materi peserta didik. (R1 dan R2, 2020)

\section{Pembahasan}

Proses pembelajaran SD Negeri 17 Pangkalpinang di saat kondisi pandemi Covid-19, seluruhnya dilaksanakan secara jarak jauh. Menurut Dohmen (1967) Pembelajaran Jarak Jauh adalah sebagai Pembelajaran mandiri yang sistemastis, yang mana konseling, pemberian materi, dan pengawasan serta pemantauan keberhasilan peserta didik yang dilakukan oleh guru sebagai penanggung jawab. Bantuan media diperlukan untuk pelaksanaan pembelajaran jarak jauh. Kebalikan dari Pembelajaran jarak jauh 
adalah tatap muka atau langsung, yaitu pembelajaran secara kontak langsung antara guru dan peserta didik. Selain itu, Pembelajaran Jarak Jauh juga dapat didefinisikan sebagai metode pembelajaran yang mana guru dan peserta didiknya belajar secara terpisah sehingga komunikasi antar keduanya harus difasilitasi oleh berbagai media, (Kahfi, 2020). Moore (Kusmiati \& Rahadi, 2020) Jadi dapat disimpulkan Pembelajaran Jarak Jauh adalah suatu bentuk pembelajaran mandiri tanpa adanya kontak langsung atau terpisah anatara guru dan peserta didik dan harus difasilitasi oleh berbagai media.

Pada pelaksanaannya baik belajar secara jarak jauh maupun belajar tatap muka langsung tetap harus memperhatikan keefektifannya dalam mencapain tujuan dan keberhasilan pembelajaran. Menurut Kamus Besar Bahasa Indonesia (KBBI), kata Keefektifan berarti hal berkesan, keadaan berpengaruh, kemanjuran, keberhasilan, (Indonesia, 2011). (Sutikno, 2005) menjelaskan efektif pada dasarnya adalah ukuran berhasil atau tidaknya suatu pencapaian tujuan suatu organisasi ataupun lembaga. Suatu organisasi atau lembaga telah mencapai tujuan, maka organisasi atau lembaga tersebut sudah berjalan efektif. Jadi dapat dikatakan pembelajaran yang efektif dapat dilihat dari berhasilnya dalam mencapai tujuan belajar peserta didik sesuai apa yang diharapkan. Salah satu faktor penentu dalam keberhasilan belajar adalah persiapan sebelum memberikan layanan belajar, terutama pada Pembelajaran Jarak Jauh yang mana adanya jarak antara guru dan peserta didik. Suatu pembelajaran dapat dikatakan efektif jika tujuan dan keberhasilan pembelajaran tercapai sesuai dengan indikator pembelajaran yang efektif. Hal ini sejalan dengan Rovai yang menyatakan desain mata pembelajaran menentukan keefektifan belajar. Dan juga, pembelajaran yang efektif atau tidak dapat dikenali dari perilaku-perilaku antara guru dan peserta didik. Mengenai respon peserta didik terhadap apa yang disampaikan oleh guru.

Menteri Pendidikan dan Kebudayaan Republik Indonesia mengeluarkan Surat Edaran No. 4 Tahun 2020 Tentang Pelaksanaan Kebijakan Pendidikan Dalam Masa Darurat Penyebaran Covid-19 yang berlaku bagi seluruh masyarakat Indonesia di semua institusi pendidikan. Disamping keharusan belajar jarak jauh, yang menjadi kendala lainnya adalah kurangnya fasilitas penunjang pembelajaran daring, namun guru berusaha mengatasi kendala tersebut dengan menganjurkan orangtua dan peserta didik untuk pergi ke sekolah mengambil materi dan tugas secara perorangan dan kemudia dipelajari dan dikerjakan dirumah. Hal ini dilakukan agar semua peserta didik dapat belajar. Namun, Pembelajaran Jarak Jauh ini tidak disambut baik sepenuhnya oleh peserta didik, karena peserta didik menganggap bahwa pembelajaran ini membuat mereka jenuh, bosan, dan dipenuhi oleh tugas. Selain itu, efektifnya suatu pembelajaran juga dipengaruhi oleh tingkat semangat belajar peserta didik. Pembelajaran ini juga menyebabkan peserta didik lebih lambat dalam menyerap pembelajaran, apalagi jika dilihat dari daya serap peserta didik yang berbeda. Ada beberapa peserta didik yang cepat menangkap pembelajaran namun ada juga beberapa yang lambat menyerap pembelajaran sehingga peserta didik ini akan tertinggal dalam pembelajaran tersebut, sehingga membuat hasil belajar yang diharapkan kurang efektif. Selain itu, nilai dan hasil belajar yang juga tidak dapat diukur dengan pasti karena guru tidak bisa memantau dan mengetahui kemampuan peserta didik secara langsung.(KEBUDAYAAN \& INDONESIA, 2020)

\section{Kesimpulan}

Pandemi covid-19 sangat berdampak terhadap bidang pendidikan di Indonesia. Pembelajaran Jarak Jauh akan terus dilakukan hingga tuntasnya wabah Covid-19 dalam upaya pencegahan dan menghentikan rantai penyebaran virus di Indonesia. Oleh karena itu hingga saat ini masih belum dapat ditentukan mengenai kapan institusi Pendidikan dibuka secara normal dengan tatap muka seperti biasanya. Pembelajaran yang dilakukan di SD Negeri 17 Pangkalpinang juga dilaksanakan secara jarak jauh. Pembelajarannya berjalan dengan cukup lancar, namun kurangnya fasilitas juga menjadi suatu hambatan berlangsungnya kegiatan belajar daring. Namun guru tidak kehabisan ide, guru merancang pembelajaran yang sesuai kemampuan dan tepat bagi seluruh peserta didik dalam proses Pembelajaran Jarak Jauh. Peserta didik pun tidak dapat menghindari rasa jenuh dan bosan yang dihadapi selama pembelajaran. Padahal, tingkat semangat belajar peserta didik juga berpengaruh pada keefektifitas pembelajaran. Dan tiap individu itu berbeda dalam menyerap materi. Nilai dan hasil pembelajaran pun tidak bisa diukur dengan pasti karena tidak bisa dipungkiri orangtualah yang sering mengerjakan tugas yang diberikan oleh guru. Hal tersebut 
tidak memenuhi indikator efektifitas pembelajaran. Oleh karena itu, dapat disimpulkan jika Pembelajaran Jarak Jauh ini kurang efektif karena kurangnya fasilitas, tingkat semangat peserta didik yang rendah, nilai dan hasil pembelajaran tidak dapat dipastikan. Tapi mau tidak mau, pembelajaran ini harus dilaksanakan dalam upaya memutuskan penyebaran Covid-19 dan demi keselamatan guru dan peserta didik.

\section{Referensi}

Bistari, B. (2017). Konsep dan indikator pembelajaran efektif. Jurnal Kajian Pembelajaran Dan Keilmuan, $1(2), 13-20$.

Hui, D. S., Azhar, E. I., Madani, T. A., Ntoumi, F., Kock, R., Dar, O., Ippolito, G., Mchugh, T. D., Memish, Z. A., \& Drosten, C. (2020). The continuing 2019-nCoV epidemic threat of novel coronaviruses to global health-The latest 2019 novel coronavirus outbreak in Wuhan, China. International Journal of Infectious Diseases, 91, 264-266.

Indonesia, K. B. B. (2011). Jakarta. Republik Indonesia.

Kahfi, A. (2020). Tantangan Dan Harapan Pembelajaran Jarak Jauh Di Masa Pandemi Covid 19. Dirasah: Jurnal Pemikiran Dan Pendidikan Dasar Islam, 3(02), 137-154.

KEBUDAYAAN, M. P. D. A. N., \& INDONESIA, R. (2020). Surat Edaran Nomor 4 Tahun 2020 tentang Pelaksanaan Kebijakan Pendidikan dalam Masa Darurat Penyebaran Coronavirus Disease (COVID-19).

Kusmiati, L. K., \& Rahadi, D. R. (2020). PENGEMBANGAN KOMPETENSI MAHASISWA DI MASA PANDEMIC COVID-19. Jurnal Manajemen Bisnis (JMB), 92-101.

Maulah, S., \& Ummah, N. R. (2020). Persepsi Mahasiswa Biologi terhadap Perkuliahan Daring Sebagai Sarana Pembelajaran Selama Pandemi Covid 19. ALVEOLI: Jurnal Pendidikan Biologi, 1(2), 49-61.

Suharsimi, A. (2006). Prosedur penelitian suatu pendekatan praktik. Jakarta: Rineka Cipta, 120-123.

Sutikno, M. S. (2005). Pembelajaran Efektif Mataram. NTP Press.

Telaumbanua, D. (2020). Urgensi Pembentukan Aturan Terkait Pencegahan Covid-19 di Indonesia. QALAMUNA: Jurnal Pendidikan, Sosial, Dan Agama, 12(1), 59-70.

Utarini, A. (2020). Tak Kenal Maka Tak Sayang: Penelitian Kualitatif dalam Pelayanan Kesehatan. UGM PRESS. 